\title{
Ski is silenced by methylation and acts as tumor suppressor in non-small cell lung cancer
}

\author{
Mian Xie ${ }^{1}$, Xiaojun $\mathrm{Wu}^{2}$, Chaosheng $\mathrm{He}^{3}$, Jiexia Zhang ${ }^{1}$, Jinjun Zhang ${ }^{4}$ \\ ${ }^{1}$ China State Key Laboratory of Respiratory Disease and Guangzhou Institute of Respiratory Disease, The First Affiliated \\ Hospital of Guangzhou Medical University, Guangzhou, China \\ ${ }^{2}$ State Key Laboratory of Oncology in Southern China, Department of Colorectal Surgery, Sun Yat-Sen University Cancer \\ Center, Guangzhou, China \\ ${ }^{3}$ Department of Internal Medicine, Guangdong General Hospital, Guangzhou, China \\ ${ }^{4}$ Department of Anesthesiology, The First Affiliated Hospital, Sun Yat-Sen University, Guangzhou, China
}

Correspondence to: Mian Xie, e-mail: mianxie@gird.cn

Keywords: lung cancer, Ski, DNA methylation, prognosis

Received: July 20, 2015

Accepted: November 22, 2015

Published: December 12, 2015

\section{ABSTRACT}

Epigenetic silencing of tumor suppressors contributes to the development and progression of lung cancer. We recently found that Ski was hypermethylated in lung cancer. This study aimed to clarify its epigenetic alteration, molecular mechanisms and clinical significance in lung cancer. Ski methylation was evaluated by methylationspecific PCR (MS-PCR) and bisulfite sequencing. mRNA level of Ski was measured by RT-PCR and compared with the methylation status. Ski methylation correlated with decreased mRNA expression in human lung cancer cell lines. Ski hypermethylation was detected in $\mathbf{5 6 . 0 \%}$ of primary lung tumors and associated with poor differentiation and late tumor stage. Demethylation agent 5-aza-2'-deoxycytidine (5-aza-2'dC) restored Ski expression. Re-expression of Ski in lung cancer cells inhibited cell proliferation, clonogenicity, migration, invasion and tumor formation. Ski decreased transcriptional activities of Smads and TAZ. Multivariate analysis showed that patients with Ski positive expression had a better overall survival in resected non-small cell lung cancer (NSCLC) patients. Our results revealed that Ski acts as a tumor suppressor inactivated by DNA methylation and is an independent prognostic factor of lung cancer.

\section{INTRODUCTION}

Ski was originally described as the oncogene present in the avian Sloan-Kettering viruses [1]; however, its oncogenic activity was rationalized upon discovering that Ski directly interacts with Smad2, Smad3 and Smad4 [25]. Ski acts in opposition to TGF- $\beta$-induced transcriptional activation by functioning as a Smad-dependent corepressor [6]. Ski contains both pro-oncogenic and antioncogenic activities in mammalian cells [7]. Shinagawa et al. found that Ski directly binds to and recruits the HDAC complex to Smads, leading to inhibition of tumor growth factor- $\beta$ (TGF- $\beta$ ) signaling. Loss of human Ski gene function may increase the susceptibility to certain types of tumors [8].

Hippo pathway is an evolutionarily conserved pathways that plays important roles in the regulation of organ size, tumorigenesis, and stem cell self-renewal
[9-17]. TAZ is well-established oncogenes [18]. Our previous study proved that overexpression of TAZ is associated with poor prognosis in resected non-small cell lung cancer (NSCLC) [19]. Rashidian et al. identified Ski as a repressor of TAZ during breast cancer progression [20]. Additional molecules or pathways regulated by Ski should be better elucidated in lung cancer.

The initiation and progression of lung cancer involves a multi-step process with sequential genetic and epigenetic changes. DNA methylation is a common mechanism of tumor suppressor gene inactivation and tumorigenesis [21-24]. Recent studies have demonstrated that a series of methylation-silenced tumor suppressor genes are associated with lung cancer progression [25-28].

The methylation status and the role of Ski in lung cancer remains unknown. In the present study, we evaluated Ski expression and DNA methylation in lung cancer cell lines and human tumor tissues. We further 
investigated the association of Ski expression with the clinicopathological characteristics and prognosis in lung cancer patients.

\section{RESULTS}

\section{Ski hypermethylation in lung cancer cell lines and tumor tissues}

We used methylation specific polymerase chain reaction (MS-PCR) to examine the methylation state of the Ski gene in NCI-H358, A549, NCI-H1299, HCC827, NCI-H1838, NCI-H292, NCI-H3255, SK-MES-1 lung cancer cells lines and normal human bronchial epithelial cell line HBE-154 (Figure 1A). The results showed that NCI-H358, A549, NCI-H1299, HCC827, and NCI-H1838 lung cancer cell lines exhibited methylation, while no methylation was found in HBE-154 cell line and other three lung cancer cell lines NCI-H1975, NCI-H292, and SK-MES-1 (Figure 1B). To provide a detailed DNA methylation within the $\mathrm{CpG}$ island region of the Ski gene, we performed bisulfite sequencing (BSP). The size of the PCR was $212 \mathrm{bp}$ and included the transcriptional start site (121 to $335 \mathrm{bp}$ ). The result of BSP was in accordance with MS-PCR, with Ski densely methylated in five lung cancer cells and unmethylated in the other three lung cancer cell lines and normal bronchial epithelial cell line (Figure 1C). In order to clarify whether $\mathrm{CpG}$ island methylation silences Ski expression, we examined mRNA expression of Ski in lung cancer cells and HBE-154 cells by reverse transcription-polymerase chain reaction (RT-PCR) and qRT-PCR assay. We found that the Ski transcription was silenced in five $(62.5 \%)$ lung cancer cells with Ski methylation. In contrast, Ski was detected in unmethylated HBE-154 cells, suggesting suppressed expression of Ski in lung cancer cells (Figure 1D-1E). We next evaluated Ski methylation status in human primary lung cancer and adjacent normal lung tissues. Using MS-PCR, we found Ski methylation in 94 out of 168 (56.0\%) lung cancer tissues compared with no methylation in normal lung tissues $(0 / 20)$ (representative results shown in Figure 1F). These data suggest that Ski hypermethylation was associated with its transcriptional inhibition or silencing. To further confirm that Ski expression was suppressed by promoter region methylation, we performed demethylation experiment. The results of RT-PCR and qRT-PCR analyses were shown in Figure 1G-1H. Demethylation agent 5-aza$2^{\prime}$-deoxycytidine (5-aza-2'dC) induced re-expression of Ski in five lung cancer cell lines with Ski methylation. There was no change of Ski expression in unmethylated lung cancer cells after 5 -aza-2'dC treatment.

\section{Ski inhibits lung cancer growth and invasion}

Epigenetic silencing of Ski expression in lung cancer suggests that Ski acts as a potential tumor suppressor in lung cancer. To further clarify this assumption, we treated A549 and HCC827 cells with demethylation agent 5-aza-2' $\mathrm{dC}$ to allow endogenous Ski to be de-repressed, and examined how Ski inhibited cell growth, soft-agar colony formation, migration, invasion and tumor growth. Cell proliferation assay showed that re-expression of Ski significantly inhibited the growth of A549 and HCC827 cells $(P<0.05)$ (Figure 2A). Similarly, colony formation assay showed that re-expression of Ski significantly reduced colony formation $(P<0.05)$ (Figure 2B). We next evaluated the effect of Ski on lung cancer cell migration and invasion. Quantitative analysis at $36 \mathrm{~h}$ showed that migration ability was significantly decreased in 5-aza-2'dC-treated lung cancer cells compared with control cells $(P<0.05)$ (Figure 2C). Cell invasion ability of 5-aza-2'dC-treated A549 and HCC827 significantly lower than that in control cells $(P<0.05)$ (Figure 2D). These results show that Ski inhibits lung cancer cell growth, migration and invasion in vitro. To further determine the tumor growth inhibition of Ski in vivo, we examined the growth inhibition by 5 -aza$2^{\prime} \mathrm{dC}$ in A549 cells with silenced Ski expression. Tumor growth was significantly inhibited in Ski re-expression nude mice than control mice, indicating that Ski acts as tumor suppressor in lung tumorigenesis $(P<0.05)$ (Figure 2E).

\section{Ski methylation in lung cancer patients}

We investigated the correlation between Ski methylation and clinical characteristics in 168 NSCLC patients. Ski methylation was detected in 94 (56.0\%) patients by MS-PCR assay. As shown in Table 1, Ski methylation was associated with poor differentiation $(P=0.01)$ and late tumor stage $(P=0.003)$. There was no correlation between Ski methylation and other clinicopathological features such as age $(P=0.07)$, gender $(P=0.12)$, smoking history $(P=0.457)$, and histological type $(P=0.58)$.

\section{Ski decreases transcriptional activities of TGF- $\beta 1$-induced Smad and TAZ}

To investigate the effect of Ski re-activation on TGF- $\beta 1 /$ Smad and Hippo/TAZ pathway, we first measured its effect on the endogenous Smad target genes (PAI-1 and $\mathrm{P} 15^{\mathrm{INK} 4 \mathrm{~B}}$ ) and TAZ target gene CTGF. Western blot assay showed that the induction of PAI-1, P15 $5^{\mathrm{INK} 4 \mathrm{~B}}$, TAZ and CTGF was significantly attenuated after re-expression of Ski by demethylation agent 5-aza-2'dC (Figure 3A).

We examined the expression level of Smads after re-expression of Ski by 5-aza-2'dC. The results showed that Ski did not significantly alter the expression levels of Smad2, Smad3 or Smad4 in A549 cells. However, a decrease in the expression of P-Smad2, P-Smad3 and P-Smad4 upon TGF- $\beta 1$ stimulation was observed in 5 -aza-2'dC-treated A549 cells compared with control cells (Figure 3B). In addition, we observed that the TGF- $\beta$ -induced nuclear translocation of Smad2, Smad3 and Smad4 was suppressed in 5-aza-2'dC-treated A549 cells 
A

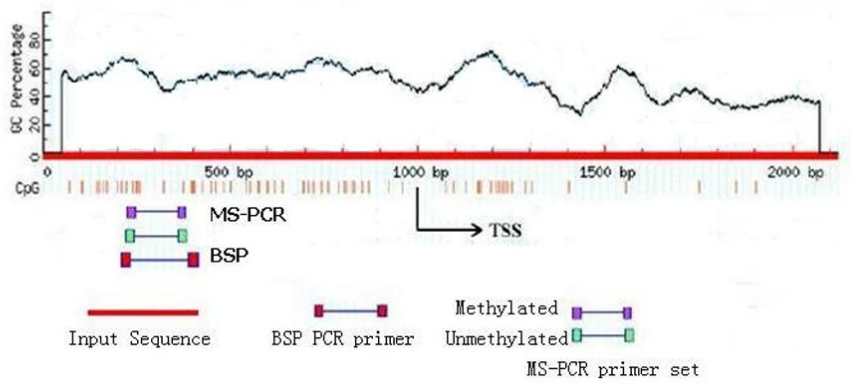

B

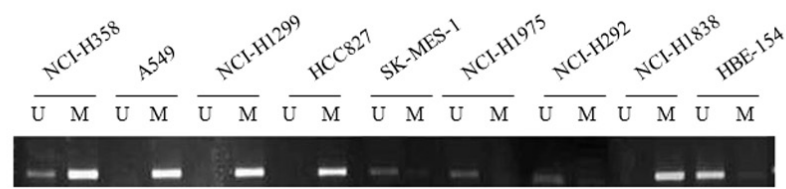

$\mathrm{C}$

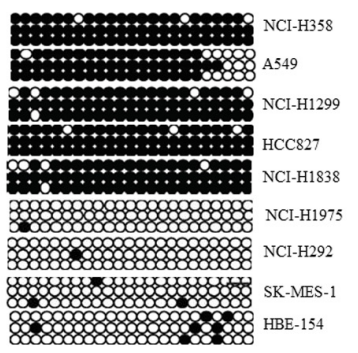

D

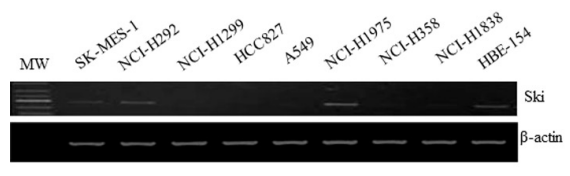

$\mathbf{E}$

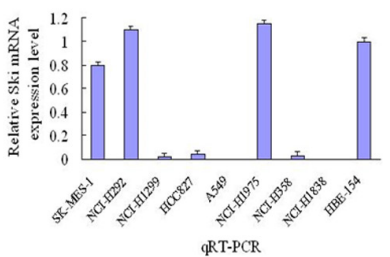

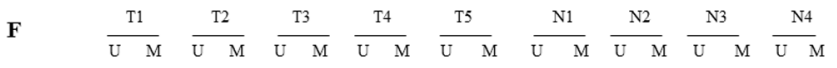

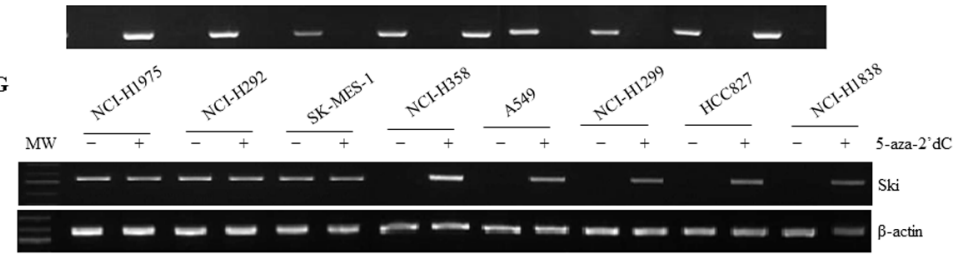

H

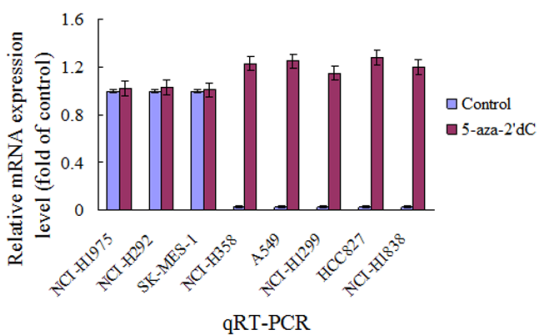

Figure 1: Ski hypermethylation in lung cancer cell lines and human lung cancer tissues. (A) Schematic for the location of the $\mathrm{CpG}$ islands in the transcription start region in Ski gene. CpG sites are indicated by vertical orange lines. The regions for MS-PCR and BSP are indicated. TSS: translation start site. (B) Representative MS-PCR in eight lung cancer cell lines and normal HBE-154 cell line. U: PCR product amplified by unmethylated-specific primers; M: PCR product amplified by methylated-specific primers. (C) Bisulfite sequencing: each dot represents a single $\mathrm{CpG}$ (black dot for methylated $\mathrm{CpG}$, white dot for unmethylated). (D) mRNA expression of Ski in lung cancer cell lines was determined by RT-PCR assay. $\beta$-actin was used as the internal control. (E) Relative mRNA expression level of Ski in cell lines was detected by qRT-PCR assay. (F) Representative results of methylation analysis by MS-PCR in human lung cancer tissues (T) and adjacent normal tissues $(\mathrm{N})$. U: unmethylation; M: methylation. (G) Eight lung cancer cell lines were treated with 5-aza-2'dC or DMSO (control). Cells were harvested and mRNA expression of Ski was analyzed by RT-PCR. $\beta$-actin was used as internal control. (H) mRNA expression of Ski in cell lines pre- and post- 5-aza-2'dC treatment was detected by qRT-PCR assay. 
A
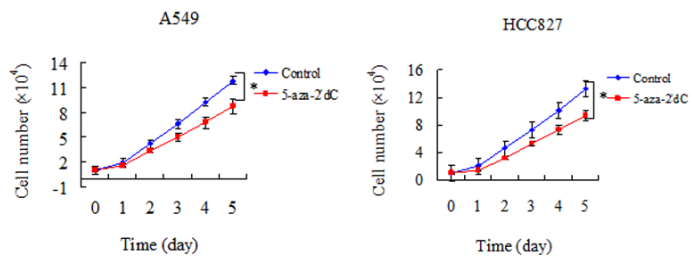

B
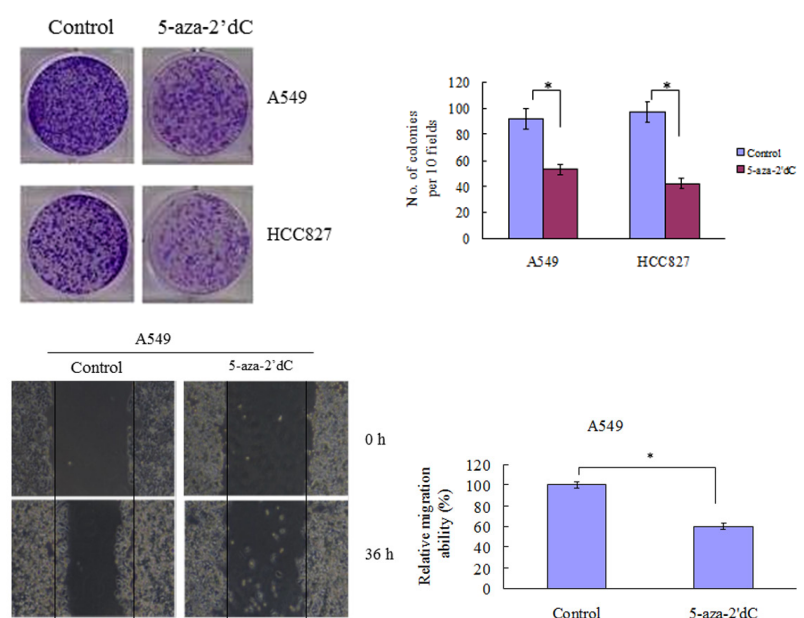

$0 \mathrm{~h}$
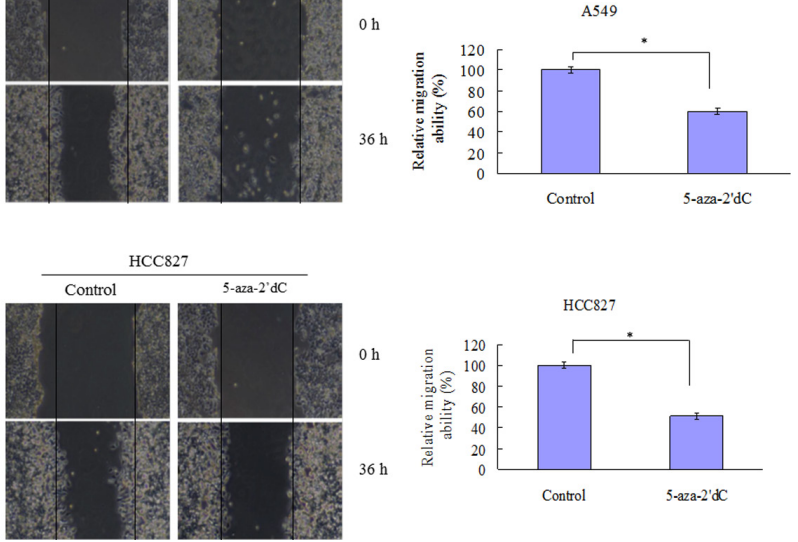

D
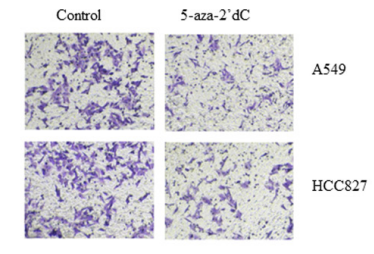

E
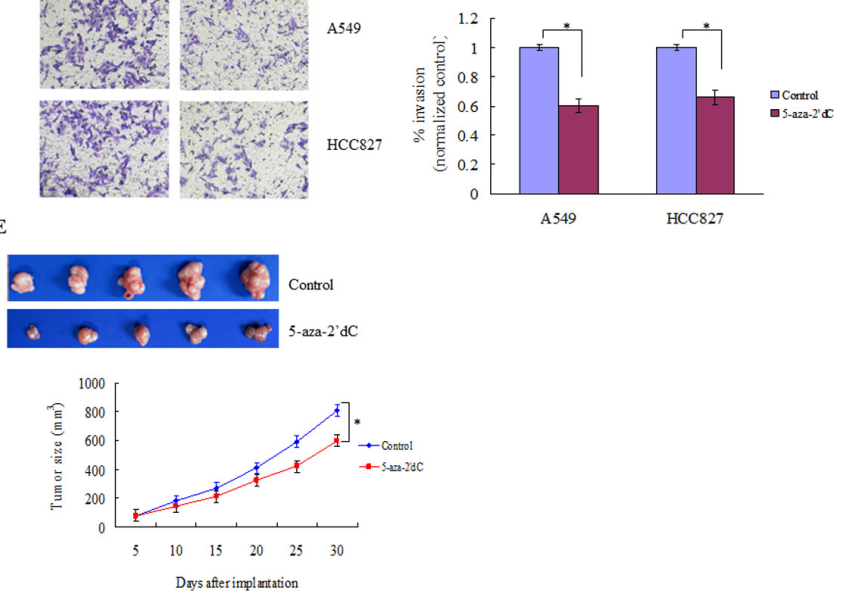

Figure 2: Ski inhibited lung cancer growth and invasion. (A) A549 and HCC 827 cells were treated with 5-aza-2'dC or DMSO. Cell proliferation was measured by Cell Counting Kit-8. Results were obtained from three independent experiments. $* P<0.05$. (B) Representative images of colony formation assay. Quantitative analysis showed a significant reduction of colony numbers in 5-aza2 'dC-treated A549 and HCC 827 cells compared with control cells. ${ }^{*} P<0.05$. (C) Effect of 5-aza-2'dC on A549 and HCC 827 cell migration. The numbers of cells after $36 \mathrm{~h}$ were obtained from three independent experiments. Results were expressed as mean $\pm \mathrm{SD}$. $* P<0.05$. (D) Cell invasion of 5-aza-2'dC-treated A549 and HCC827 cells and control cells was analyzed by Transwell assay. Results were obtained from three independent experiments and expressed as mean \pm SD. ${ }^{*} P<0.05$. (E) A549 cells $\left(5 \times 10^{6}\right.$ cells in 0.2 mL PBS $)$ were injected subcutaneously into the right dorsal flank of 4-week-old female BALB/c nude mice. $1 \mu \mathrm{g} / \mathrm{kg} 5$-aza-2'dC or DMSO was injected into the mice intraperitoneally (i.p.) three times per week for four weeks. 5-aza-2'dC significantly inhibited tumor growth derived from A549 cells in nude mice. ${ }^{*} P<0.05$. 
Table 1: Clinical characteristics and Ski methylation in 168 resected lung cancer patients

\begin{tabular}{|c|c|c|c|c|}
\hline \multirow[b]{2}{*}{ Clinical characteristics } & \multirow[b]{2}{*}{ Number } & \multicolumn{2}{|c|}{ Ski methylation } & \multirow[b]{2}{*}{$P$} \\
\hline & & Methylated & Unmethylated & \\
\hline Age (years) & & & & 0.07 \\
\hline$\leq 60$ & 71 & 35 & 36 & \\
\hline$>60$ & 97 & 59 & 38 & \\
\hline Gender & & & & 0.12 \\
\hline Male & 116 & 72 & 44 & \\
\hline Female & 52 & 22 & 30 & \\
\hline Smoking history & & & & 0.457 \\
\hline Never smoker & 32 & 19 & 13 & \\
\hline Former smoker & 136 & 75 & 61 & \\
\hline Tumor differentiation & & & & 0.01 \\
\hline Poor & 92 & 66 & 26 & \\
\hline Well/moderate & 76 & 28 & 48 & \\
\hline Histology & & & & 0.58 \\
\hline Adenocarcinoma & 95 & 56 & 39 & \\
\hline Squamous carcinoma & 58 & 26 & 32 & \\
\hline Others & 15 & 12 & 3 & \\
\hline Tumo & & & & 0.003 \\
\hline Stage I & 46 & 6 & 40 & \\
\hline Stage II/ III & 122 & 88 & 34 & \\
\hline
\end{tabular}

(Figure 3C). The results indicated that enforced expression of Ski blocked nuclear translocation of endogenous Smads. Thus, Ski exerted its inhibitory activity in TGF- $\beta 1 /$ Smad signaling pathway.

Ski reduced endogenous TAZ abundance while had a minor effect on the activity of phosphorylation of TAZ (P-TAZ). However, in the presence of Lats2, Ski significantly increased the P-TAZ. Phosphorylation of TAZ may lead to its degradation in an ubiquitination-and proteasome-dependent manner or alter its intracellular localization [29]. However, we found that Ski did not affect the localization of P-TAZ and TAZ (Figure 3D). The above results revealed that Ski inhibited TAZ by increasing their phosphorylation by Lats 2 and did not alter the localization of TAZ.

\section{Association of Ski expression with clinicopathological characteristics as well as prognosis in NSCLC patients}

To evaluate the clinical significance of Ski, immunohistochemical (IHC) analysis of 168 resected NSCLC patients was performed. The overall follow-up durations ranged from 24 to 89 months (median, 52.3 months). We found that Ski was expressed at low levels in lung cancer tissues while expressed at high levels in adjacent normal lung tissues (Figure 4A). The patients' characteristics and their correlation with Ski expression is shown in Table 2. We found that Ski positive expression was significantly correlated with well tumor differentiation $(P=0.012)$ and early tumor stage $(P=0.002)$ but not with tumor histology $(P=0.262)$, age $(P=0.611)$, gender $(P=0.251)$, and smoking history $(P=0.083)$. There was a statistically significant negative correlation between Ski promoter methylation and its protein expression. The 74 samples with unmethylated Ski exhibited positive protein expression, while the 94 samples with methylated Ski were negative for protein expression. Kaplan Meier survival curves showed that lung cancer patients with Ski positive expression had significantly longer overall survival (OS) than those with negative Ski expression $(P=0.02$, logrank test; Figure 4B).

Stage I lung cancer patients with negative Ski expression showed a significantly poorer survival than patients with positive Ski expression ( $P=0.017$; Figure 4C). There was no significant difference of median OS between those with positive and negative expression in stage II/III lung cancer patients $(P=0.981$; Figure 4D).

In the univariate Cox regression analysis, Ski positive expression was associated with a decreased 
risk of cancer-related death (hazard ratio $(\mathrm{HR})=0.490$; $95 \%$ confidence interval $(\mathrm{CI}), 0.227-0.618 ; P=0.003)$. After adjustment for potential confounding factors, Ski positive expression was found to predict better survival $(\mathrm{HR}=0.357 ; 95 \% \mathrm{CI}, 0.154-0.518 ; P=0.001)$ in the

A

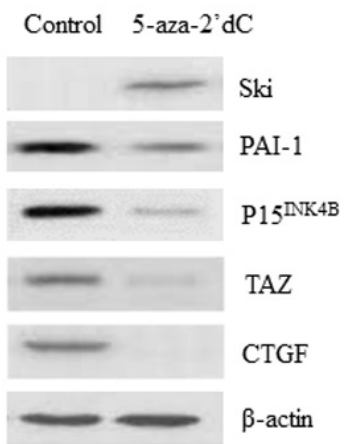

C

Cytoplasm

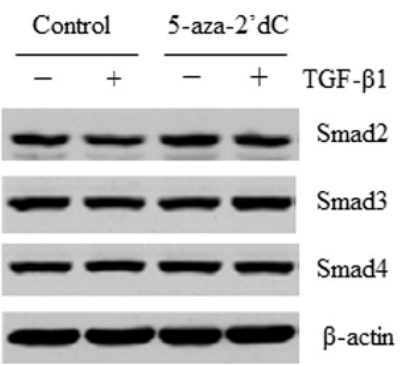

D

Cytoplasm

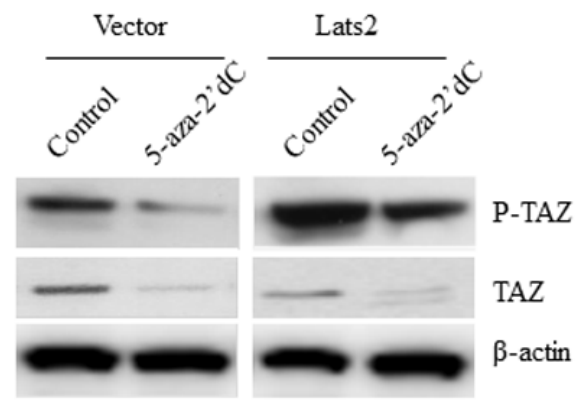

multivariate model (Table 3). This suggests that Ski positive expression was an independent predictor of better survival of resected NSCLC patients. As expected, tumor stage was another independent predictor for overall survival.

B

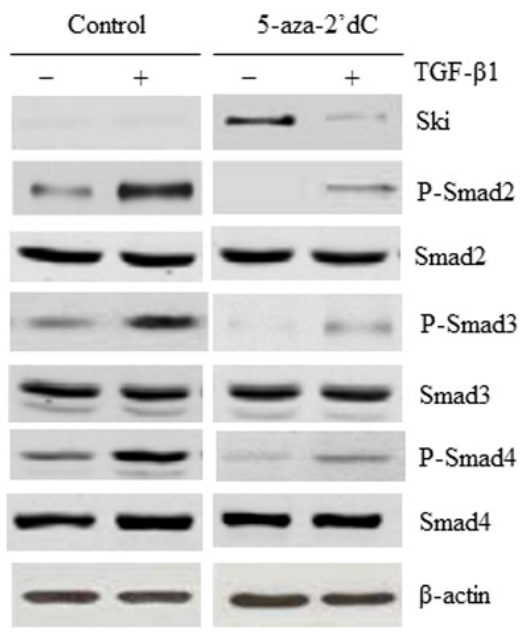

Nucleus

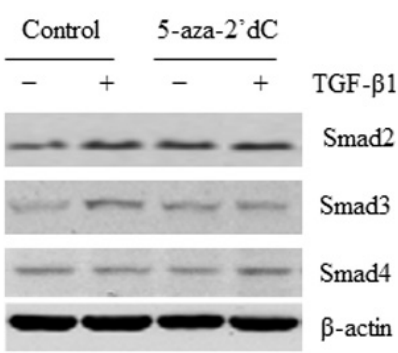

Nucleus

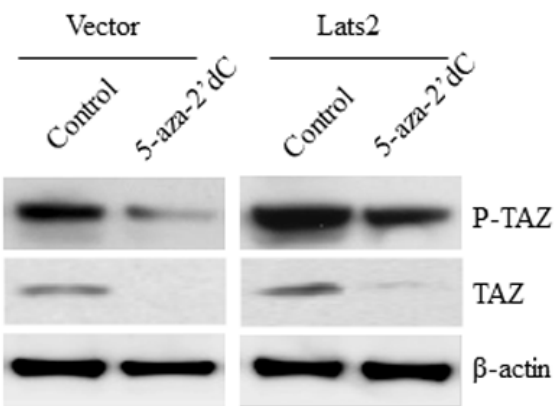

Figure 3: Ski decreased transcriptional activities of TGF- $\beta 1$-induced Smad and TAZ in lung cancer cells. (A) Protein expressions of Ski, PAI-1, P15 ${ }^{\mathrm{INK} 4 \mathrm{~B}}$, TAZ, and CTGF were examined by western blotting assay in 5-aza-2'dC-treated and control cells. $\beta$-actin was used as a loading control. (B) Re-activation of Ski by 5-aza-2'dC decreased the induction of P-Smad2, Smad2, P-Smad3, Smad3, P-Smad4 and Smad4 in A549 cells. Cells were either uninduced or induced with TGF- $\beta 1$ (200 pM) for 20 minutes. Whole cell extracts were analyzed by western blotting. (C) Nuclear and cytoplasmic extracts from A549 cells either uninduced or induced with TGF- $\beta 1$ $(200 \mathrm{pM})$ were analyzed by Western blotting with anti-Smad2, anti- $\beta$-actin (cytoplasm), or anti-lamin (nucleus). (D) The left panels are immunoblotting of cytoplasmic lysates. The right panels are immunoblotting of nucleus lysates. A549 cells transfected with control vector or Lats2 were treated with 5-aza-2'dC or DMSO. Cytoplasmic and nuclear cell lysates were separated. And these cell lysates were subjected to immunoblotting with the TAZ and pTAZ. 


\section{DISCUSSION}

DNA methylation plays an important role in carcinogenesis, especially at early stages [30, 31]. Epigenetic changes frequently occur in lung cancer, including DNA methylation, which influences the accessibility of the underlying DNA to transcriptional regulatory factors that activate or repress expression [32]. The Ski gene family is involved in methyl CpGmediated transcriptional repression and required for $\mathrm{MeCP} 2$-mediated transcriptional repression [33]. In current study, we investigated the epigenetic alteration of
Ski and its function in NSCLC. We found that Ski was hypermethylated in human primary lung cancer tissues but not in adjacent normal lung tissues. Furthermore, the methylation frequency correlated with advanced tumor stage and poor differentiation. Decreased Ski expression was at least partially attributed to epigenetic changes in the Ski promoter region. Ski expression in methylated lung cancer cells was markedly increased after 5-aza2 'dC treatment. Collectively, our data reveal that DNA methylation of Ski suppresses its transcriptional level, which may be responsible for the development of lung cancer.
A

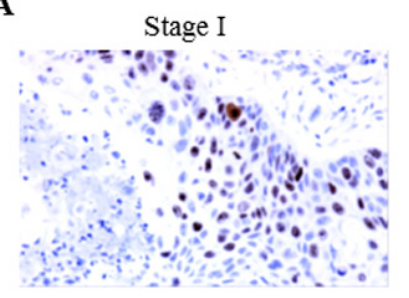

Stage III

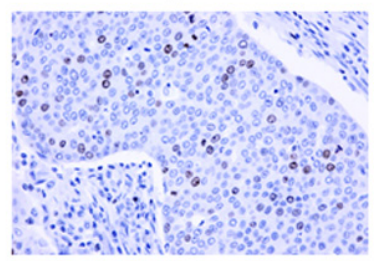

Negative control

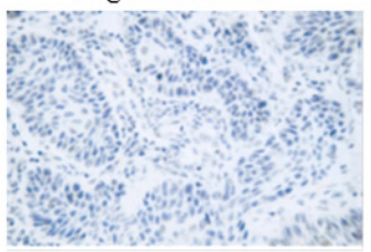

B

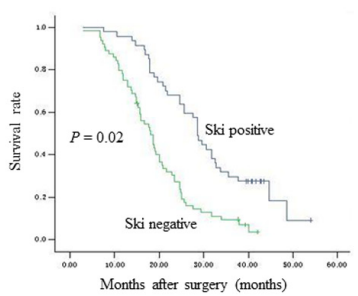

D

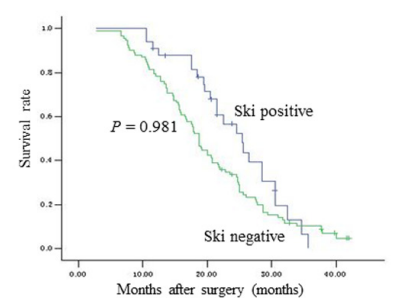

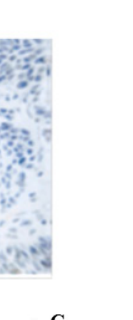

C

Stage II

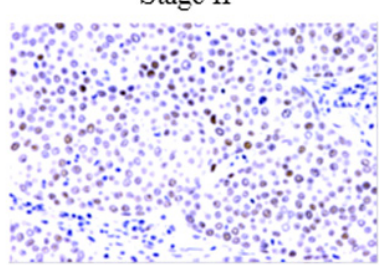

Normal lung tissue
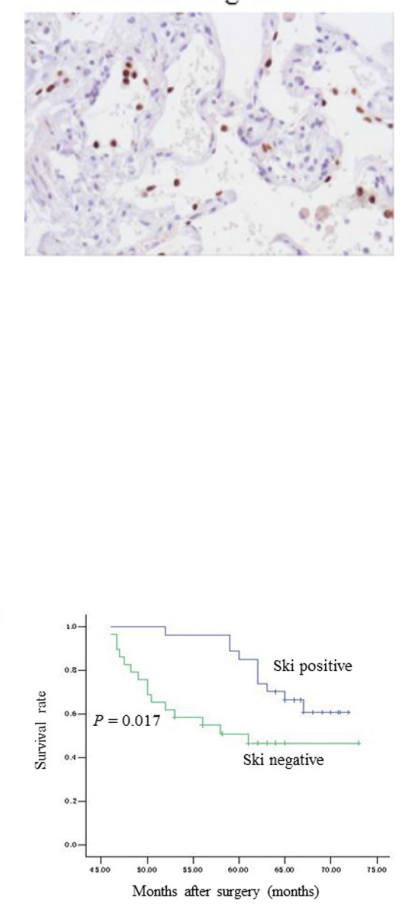

Figure 4: Ski expression in resected NSCLC and its association with overall survival time. (A) Immunohistochemical staining for Ski in resected NSCLC tissues. Original magnification, 200×. (B) Kaplan-Meier survival curve of NSCLC patients with or without Ski expression. The survival of patients whose cancer cells express Ski $(n=74)$ was significantly better than that of patients whose cancer cells did not express Ski $(n=94)(P=0.02)$. (C) Kaplan-Meier curves of stage I NSCLC patients with or without Ski expression $(n=46)(P=0.017)$. (D) Kaplan-Meier curves of stage II-III NSCLC patients with or without Ski expression $(n=122)(P=0.981)$. 
Table 2: Correlation between Ski expression and clinicopathological factors in resected NSCLC patients $(n=168)$

\begin{tabular}{|c|c|c|c|c|}
\hline \multirow[b]{2}{*}{ Clinical characteristics } & \multirow[b]{2}{*}{ Number } & \multicolumn{2}{|c|}{ Ski expression } & \multirow[b]{2}{*}{$P$} \\
\hline & & $\begin{array}{c}\text { Positive } \\
n=74\end{array}$ & $\begin{array}{c}\text { Negative } \\
n=94\end{array}$ & \\
\hline Age (years) & & & & 0.611 \\
\hline$\leq 60$ & 71 & 40 & 31 & \\
\hline$>60$ & 97 & 34 & 63 & \\
\hline Gender & & & & 0.251 \\
\hline Male & 116 & 50 & 66 & \\
\hline Female & 52 & 24 & 28 & \\
\hline Smoking history & & & & 0.083 \\
\hline Never smoker & 32 & 14 & 18 & \\
\hline Former smoker & 136 & 60 & 76 & \\
\hline Tumor differentiation & & & & 0.012 \\
\hline Poor & 92 & 22 & 70 & \\
\hline Well/moderate & 76 & 52 & 24 & \\
\hline Histology & & & & 0.262 \\
\hline Adenocarcinoma & 95 & 30 & 65 & \\
\hline Squamous carcinoma & 58 & 38 & 20 & \\
\hline Others & 15 & 6 & 9 & \\
\hline Tumor stage & & & & 0.002 \\
\hline Stage I & 46 & 40 & 6 & \\
\hline Stage II / III & 122 & 34 & 88 & \\
\hline
\end{tabular}

Ski is located at chromosome 1p36, a tumor suppressor locus frequently deleted in melanoma and neuroblastoma [34-36]. Decreased Ski abundance in breast and lung cancer cells enhances tumor progression and metastasis in vivo [37]. However, Ski may act as a tumor proliferation-promoting factor or as a metastatic suppressor in human pancreatic cancer [38]. The mechanisms underlying these conflicting observations have not been fully understood. From our findings, we propose the hypothesis that Ski expression may function as a potential tumor suppressor in lung cancer.

To explore the tumor suppressive function of Ski in lung cancer, functional analysis of Ski was performed in vitro and in vivo. We found that Ski inhibited lung cancer cell growth, colony formation, migration as well as tumor formation. Ski exerts its biological functions through interaction with various cellular partners, among which the association with the Smad proteins of the TGF- $\beta$ signaling pathway is the best characterized [2-6]. In our study, we observed that target genes of TGF- $\beta$ signaling, PAI-1 and P15 $5^{\mathrm{INK} 4 \mathrm{~B}}$, were significantly inhibited when Ski was re-expressed. Consistent with this, we also observed that A549 lung cancer cells with Ski reactivation showed decreased expression of P-Smad2, P-Smad 3 and P-Smad 4 after TGF- $\beta$ stimulation. Our data show that Ski overexpression is associated with impaired nuclear translocation of Smads, which is in agreement with published investigation proving Ski prevents the accumulation of a functional Smad2 in the nucleus [39]. All of these results confirmed that Ski could suppress the tumor-promoting activity of TGF- $\beta / \mathrm{Smad}$ in lung cancer.

To uncover additional pathways regulated by Ski, we identified Hippo signaling component TAZ as potential downstream of Ski in lung cancer. TAZ is a critical effector of the Hippo pathway and plays an essential role in cancer progression because high amounts of TAZ can promote tumor growth, EMT, and cancer stem cell expansion [40, 41]. Our work has revealed another important mechanism by which Ski inhibited TAZ by increasing their phosphorylation by Lats 2 .

At this time, it is difficult to evaluate the regulatory effect of TGF- $\beta$ and Hippo signaling on Ski gene. Our study shows that Ski acts as an important tumor suppressor by inhibiting both TGF- $\beta /$ Smad and Hippo/TAZ signaling in lung cancer.

We further evaluate the clinical significance and prognostic value of Ski in lung cancer. Ski positive expression was found to predict better survival in the multivariate model. These results indicate that Ski expression could be an independent prognostic marker 
Table 3: Univariate and multivariate Cox regression analysis of prognostic factors for resected NSCLC patients

\begin{tabular}{|c|c|c|c|c|c|c|}
\hline \multirow[b]{2}{*}{ Variables } & \multicolumn{3}{|c|}{ Univariate analysis } & \multicolumn{3}{|c|}{ Multivariate analysis } \\
\hline & HR & $95 \% \mathrm{CI}$ & $P$ & HR & $95 \% \mathrm{CI}$ & $P$ \\
\hline \multicolumn{7}{|l|}{ Age (years) } \\
\hline$\leq 60$ & 1.00 & & 0.079 & & & \\
\hline$>60$ & 1.18 & $0.966-1.879$ & & & & \\
\hline \multicolumn{7}{|l|}{ Gender } \\
\hline Male & 1.00 & & 0.228 & & & \\
\hline Female & 0.88 & $0.710-1.085$ & & & & \\
\hline \multicolumn{7}{|l|}{ Smoking history } \\
\hline Never smoker & 1.00 & & 0.377 & & & \\
\hline Former smoker & 1.261 & $0.956-1.563$ & & & & \\
\hline \multicolumn{7}{|l|}{ Tumor differentiation } \\
\hline Poor & 1.00 & & 0.902 & & & \\
\hline Well/moderate & 0.925 & $0.871-1.119$ & & & & \\
\hline \multicolumn{7}{|l|}{ Histology } \\
\hline Adenocarcinoma & 1.00 & & 0.890 & & & \\
\hline Squamous carcinoma & 0.989 & $0.870-1.059$ & & & & \\
\hline Others & 0.980 & $0.889-1.068$ & & & & \\
\hline \multicolumn{7}{|l|}{ Tumor stage } \\
\hline Stage I & 1.00 & & $<0.001$ & 1.00 & & $<0.001$ \\
\hline Stage II / III & 3.391 & $2.670-4.075$ & & 3.778 & $2.783-4.351$ & \\
\hline \multicolumn{7}{|l|}{ Ski expression } \\
\hline Negative & 1.00 & & 0.003 & 1.00 & & 0.001 \\
\hline Positive & 0.490 & $0.227-0.618$ & & 0.357 & $0.154-0.518$ & \\
\hline
\end{tabular}

for resected NSCLC patients. Subgroup analysis showed that negative Ski expression was significantly associated with shorter survival for Stage I lung cancer patients. These data suggest that Ski methylation may specifically predict the aggressive type in early stage lung cancer patients.

In summary, our study identified Ski as a functional tumor suppressor with frequent epigenetic inactivation in lung cancer. The methylation-mediated silencing of Ski may serve as a therapeutic target for lung cancer patients. However, further investigations are needed to delineate the Ski signaling pathway.

\section{MATERIALS AND METHODS}

\section{Cells lines, antibodies and reagents}

Eight lung cancer cell lines (NCI-H358, A549, NCI-H1299, HCC827, NCI-H1838, NCI-H1975, NCI-H292, and SK-MES-1), and normal human bronchial epithelial cell line HBE-154 were purchased from the American Type Culture Collection (Manassas, VA). These cell lines were routinely cultured in RPMI-1640 supplemented with 10\% fetal bovine serum (FBS) at $37^{\circ} \mathrm{C}$ in a $5 \% \mathrm{CO}_{2}$ atmosphere. Primary antibodies of Ski, TAZ, CTGF, PAI-1, P15 ${ }^{\text {INK4B }}$, phosphorylated Smad2 (P-Smad2), Smad2, P-Smad3, Smad3, P-Smad4, Smad4, P-TAZ, $\beta$-actin, and lamin used for western blotting were purchased from Santa Cruz Biotechnology Inc. (CA, USA). 5-aza-2'-deoxycytidine (5-aza-2'dC) was purchased from R \& D Inc. (Shanghai, China). Human recombinant TGF- $\beta 1$ was obtained from PeproTech (Rocky Hill, NJ).

\section{Methylation specific polymerase chain reaction (MS-PCR) and bisulfite sequencing (BSP)}

A DNA extraction kit (Qiagen Corporation, USA) was used to isolate genomic DNA from the cell lines and tissues. DNA was chemically modified using an EZ DNA Methylation-Gold Kit (Zymo Research, Orange, CA) 
as described elsewhere [24]. Primer pairs that specifically amplified either methylated or unmethylated sequences spanning the $\mathrm{CpG}$ island of human Ski are used for MSPCR (Supplementary Table 1). Normal blood genomic DNA untreated and treated with SssI methylase (New England Biolabs, Beverly, MA) was used as fully methylated and fully unmethylated controls in all PCRs, respectively. PCR products $(10 \mu \mathrm{L})$ were resolved by electrophoresis on 3\% agarose gels and visualized under UV illumination. Each sample was amplified to confirm the results.

For BSP, $1 \mu \mathrm{L}$ bisulfite-treated DNA was amplified by PCR using the primers listed in Supplementary Table 1. PCR products were purified with a Wizard SV Gel and PCR Clean-up System (Promega) and then cloned into a pGEM-T easy vector (Promega). Ten colonies were chosen randomly for plasmid DNA extraction using a Promega Spin Mini kit (Promega) and were then sequenced by an ABI 3130 Genetic Analyzer (Applied Biosystems, Foster City, CA).

\section{Demethylation treatment}

Cells were seeded at a density of $1 \times 10^{6}$ cells $/ \mathrm{mL}$ in $10 \mathrm{~cm}$ dishes. After $24 \mathrm{~h}$ of culture, cells were exposed to 5 -aza-2' $\mathrm{dC}$ at a concentration of $10 \mu \mathrm{M}$ for 3 days.

\section{Reverse transcriptase-polymerase chain reaction (RT-PCR)}

RNA was isolated using the Trizol Plus kit (TaKaRa, Japan). First-strand cDNA synthesis was performed using Invitrogen kit. Subsequent PCR reactions were performed using an RNA-PCR kit (Takara, Japan). $\beta$-actin was used as an internal control. The forward and reverse primer sequences were shown in Supplementary Table 1.

\section{Real-time qRT-PCR analysis}

Total RNA was extracted from the cells $\left(1 \times 10^{6}\right.$ cells) using Trizol plus kit (TaKaRa, Japan). Firststrand cDNA synthesis was performed using Promega kit. Synthesized cDNA was used for qRT-PCR analysis using Lightcycler (Roche, Switzerland) based on the manufacturer's instructions. $\beta$-actin was used as an internal control. All samples were amplified in duplicates. Relative changes in the amount of transcripts in each sample were determined with $\beta$-actin normalization of mRNA levels.

\section{Western blotting analysis}

Total protein was isolated from cells using cell extraction buffer (Biosource, Camarillo, CA) supplemented with protease and phosphatase inhibitors. Protein concentrations were measured using a BCA
Protein Assay kit (Pierce, Rockford, IL). Antibodies against Ski, TAZ, CTGF, PAI-1, P15 ${ }^{\mathrm{INK} 4 \mathrm{~B}}$, P-TAZ P-Smad2, Smad2, P-Smad3, Smad3, P-Smad4 and Smad4 were used as primary antibodies. The blots were incubated with a horseradish peroxidase-conjugated goat anti-rabbit antibody (Santa Cruz Biotechnology). Proteins were visualized with electrochemical luminescence (GE Healthcare, CA).

\section{Cytosolic and nuclear fractionation}

Cells were lysed in hypotonic buffer for 15 minutes at $4{ }^{\circ} \mathrm{C}$ and centrifuged at $1000 \mathrm{rpm}$ for 10 minutes. The supernatant was collected and designated as the cytosolic fraction. The pellet was resuspended in nuclear buffer, incubated for 20 minutes at $4^{\circ} \mathrm{C}$, and centrifuged at 13000 rpm for 5 minutes. The supernatant was collected and designated as the nuclear fraction.

\section{Assessment of tumorigenicity in vivo}

Tumourigenicity in nude mice was determined as described previously [42]. All experimental procedures were approved by the Animal Ethics Committee of the Guangzhou Medical University. A549 cells $\left(5 \times 10^{6}\right.$ cells in $0.2 \mathrm{~mL}$ PBS) were injected subcutaneously into the right dorsal flank of 4-week-old female BALB/c nude mice. Two weeks after inoculation, subcutaneous tumors that were formed and visible in all mice were size-matched (the diameter of each tumor was approximately $2 \mathrm{~mm}$ ), and the mice were randomly assigned to two groups (five mice each) for treatment with dimethyl sulfoxide (DMSO) or 5-aza-2'dC. $1 \mu \mathrm{g} / \mathrm{kg} 5$-aza-2'dC or DMSO was injected into the mice intraperitoneally (i.p.) three times per week for four weeks. Tumor volume was calculated using the

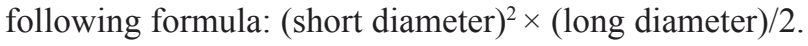
Tumor volume was assessed every three days for four weeks.

\section{Immunohistochemical (IHC) analysis and MS-PCR assay in resected lung cancer patients}

A total of 168 consecutive NSCLC patients who underwent complete resection (lobectomy and mediastinal lymph node dissection with microscopic examination of margins showing no tumor cells) from June 2006 to March 2007 at the First Affiliated Hospital of Guangzhou Medical University were included in this study. Patients who received pre-operative chemotherapy/radiotherapy and had second primary tumor were excluded. 168 primary lung cancer tissues and 20 adjacent normal lung tissues were obtained for both IHC and MS-PCR study. The histological diagnosis was based on the criteria of the World Health Organization/International Association for the Study of Lung Cancer (WHO/IASLC) classification of lung and pleural tumors [43]. Each case was reassigned for tumor, node, metastasis (TNM) classification and 
pathological stage on the basis of the IASLC staging system [44].

All experiments and procedures were approved by the Clinical Research Ethics Committee of Guangzhou Medical University. Written informed consents were obtained from all subjects. The survival time was calculated from the date of diagnosis to the date of death caused by lung cancer or December 2014, the followup cut-off date. Patients who died of causes other than lung cancer and patients who still alive at the time of the follow-up cut-off were censored.

Specimens were fixed in $10 \%$ formalin and embedded in paraffin wax. Unstained $3 \mathrm{~mm}$ sections were then cut from paraffin blocks for immunohistochemical analysis. The sections were stained with anti-Ski polyclonal antibody (Santa Cruz Biotechnology, CA, USA) as described previously and the evaluation of Ski expression was also performed accordingly [45]. All procedures were done by two independent assessors and one pathologist. Immunoreactivity was scored on a scale of 0-4 for 1) staining intensity (negative, low, medium, high, very high) and 2) percentage of positive cells $(0,<25 \%, 25-50 \%,>50 \%, \sim 100 \%)$ [46]. The sample was considered negative if score $\leq 5$ and positive if score $>5$. A negative control was prepared by substituting normal primary antibody, and no staining was detected.

Genomic DNA isolation and MS-PCR were conducted as described above.

\section{Cell proliferation assay and colony formation assay}

For cell proliferation assay, lung cancer cells $\left(5 \times 10^{3}\right.$ per well $)$ were seeded in 96 -well plates. After 5 days, cell viability was determined using the Cell Counting Kit-8 (Dojindo, Kumamoto, Japan) according to the manufacturer's instructions. Experiments were carried out in triplicate. For colony formation assay, cells were suspended with $0.4 \%$ low-melting-point agarose (Biowhittaker Molecular Application, Rockland, ME) in RPMI-1640 containing 10\% FBS. The upper layer was seeded onto $60 \mathrm{~mm}$ dishes coated with $0.5 \%$ low-meltingpoint agarose in RPMI-1640 with 10\% FBS. Medium was changed every three days for two weeks. The number of colonies that were $200 \mu \mathrm{M}$ or larger were counted.

\section{Cell migration and invasion assay}

Matrigel (BD Biosciences, USA) was applied to the upper chamber. Cells were trypsinized and seeded at $5 \times 10^{4}$ cells per insert in $100 \mu \mathrm{L}$ serumfree DMEM medium. Inserts were placed in $600 \mu \mathrm{L}$ DMEM medium with $10 \%$ FBS. The cells were incubated for $24 \mathrm{~h}$ with $5 \% \mathrm{CO}_{2}$ humidified atmosphere.
Then the cells on the upper surface of the filters were completely removed by wiping with a cotton swab. The inserts were fixed in $4 \%$ polyfluoroalkoxy (PFA) for $30 \mathrm{~min}$ and stained with crystal violet staining solution (Beijing Zhongshan Biotechnology, China). The images were taken at $200 \times$ magnification with an Olympus microscope (Olympus Corporation, Japan). For invasion assay, the numbers of cells attached to the other side of the insert were counted under a light microscope in 8 random fields at a magnification of $200 \times$. For migration assay, after photographed, the cells migrated to the underside were eluted by $33 \%$ acetic acid, and the O.D. values of absorbance were measured by VarioskanFlash (Thermo, USA) at $570 \mathrm{~nm}$. The data shown were representatives of three independent experiments.

\section{Transfection}

The plasmid for pCMVmyc-Lats2 was a gift from Sun yat-sen University Cancer Center. Full Lats2 cDNA was released from the pCMVmyc-Lats2 plasmid by BamHI and XhoI cleavage and recloned into the pcDNA3 vector to produce pcDNA3-Lats2.

Transfection of plasmid was performed with Lipofectamine ${ }^{\mathrm{TM}} 2000$ transfection reagent (Invitrogen, USA) following the manufacturer's protocol. Transfected cells were grown at $37^{\circ} \mathrm{C}$ for $6 \mathrm{~h}$, followed by incubation with complete medium.

\section{Statistical analysis}

Data are presented as the mean \pm standard deviations (SD). All statistical analyses were performed using the SPSS 16.0 software package. Comparisons between groups were evaluated using Student's $t$-test or Fisher exact test. Survival curves were assessed via the KaplanMeier method and compared with the log-rank test. A two-sided value of $P<0.05$ was considered statistically significant. The Cox proportional hazard regression model was used for both univariate and multivariate analyses of survival and for estimating the hazard ratio (HR) with $95 \%$ confidence interval $(\mathrm{CI})$. Significant variables $(P<0.1)$ in univariate analysis were included in multivariate analysis.

\section{ACKNOWLEDGMENTS AND FUNDINGS}

This work was supported by grants from the National Natural Science Foundation of China (81301999) and Natural Science Foundation of Guangdong Province in China (S2013040014688) to Mian Xie.

\section{CONFLICTS OF INTEREST}

The authors declare that there are no conflicts of interest. 


\section{REFERENCES}

1. Li Y, Turck CM, Teumer JK, Stavnezer E. Unique sequence, ski, in Sloan-Kettering avian retroviruses with properties of a new cell-derived oncogene. J Virol. 1986; 57:1065-1072.

2. Akiyoshi S, Inoue H, Hanai J, Kusanagi K, Nemoto N, Miyazono K, Kawabata M. c-Ski acts as a transcriptional co-repressor in transforming growth factor- $\beta$ signaling through interaction with smads. J Biol Chem. 1999; 274: 35269-35277.

3. Sun Y, Liu X, Eaton EN, Lane WS, Lodish HF, Weinberg RA. Interaction of the Ski oncoprotein with Smad3 regulates TGF- $\beta$ signaling. Mol Cell. 1999; 4:499-509.

4. Sun Y, Liu X, Ng-Eaton E, Lodish HF, Weinberg RA. SnoN and Ski protooncoproteins are rapidly degraded in response to transforming growth factor $\beta$ signaling. Proc Natl Acad Sci U S A. 1999; 96: 12442-12447.

5. Luo K, Stroschein SL, Wang W, Chen D, Martens E, Zhou S, Zhou Q. The Ski oncoprotein interacts with the Smad proteins to repress TGF $\beta$ signaling. Genes Dev. 1999; 13: 2196-2206.

6. Weidong $\mathrm{Xu}$, Konstantina Angelis, David Danielpour, Maher M. Haddad, Oliver Bischof, Judith Campisi, Ed Stavnezer, Estela E. Medrano. Ski acts as a co-repressor with $\mathrm{Smad} 2$ and $\mathrm{Smad} 3$ to regulate the response to type $\beta$ transforming growth factor. Proc Natl Acad Sci U S A. 2000; 97: 5924-5929.

7. Vo BT, Cody B, Cao Y, Khan SA. Differential role of SloanKettering Institute (Ski) protein in Nodal and transforming growth factor- $\beta$ (TGF- $\beta$ )-induced Smad signaling in prostate cancer cells. Carcinogenesis. 2012; 33:2054-2064.

8. Shinagawa $\mathrm{T}$, Nomura $\mathrm{T}$, Colmenares C, Ohira $\mathrm{M}$, Nakagawara A, Ishii S. Increased susceptibility to tumorigenesis of ski-deficient heterozygous mice. Oncogene. 2001; 20: 8100-8108.

9. Dong J, Feldmann G, Huang J, Wu S, Zhang N, Comerford SA, Gayyed MF, Anders RA, Maitra A, Pan D. Elucidation of a universal size-control mechanism in Drosophila and mammals. Cell. 2007; 130: 1120-1133.

10. Song H, Mak KK, Topol L, Yun K, Hu J, Garrett L, Chen Y, Park O, Chang J, Simpson RM, Wang CY, Gao B, Jiang J, et al. Mammalian Mst1 and Mst2 kinases play essential roles in organ size control and tumor suppression. Proc Natl Acad Sci USA. 2010; 107: 1431-1436.

11. Lee KP, Lee JH, Kim TS, Kim TH, Park HD, Byun JS, Kim MC, Jeong WI, Calvisi DF, Kim JM, Lim DS. The Hippo-Salvador pathway restrains hepatic oval cell proliferation, liver size, and liver tumorigenesis. Proc Natl Acad Sci USA. 2010; 107: 8248-8253.

12. McClatchey AI, Saotome I, Mercer K, Crowley D, Gusella JF, Bronson RT, Jacks T. Mice heterozygous for a mutation at the Nf2 tumor suppressor locus develop a range of highly metastatic tumors. Genes Dev. 1998; 12: 1121-1133.
13. Lai ZC, Wei X, Shimizu T, Ramos E, Rohrbaugh M, Nikolaidis N, Ho LL, Li Y. Control of cell proliferation and apoptosis by Mob as tumor suppressor, mats. Cell. 2005; 120: 675-685.

14. Tapon N, Harvey KF, Bell DW, Wahrer DC, Schiripo TA, Haber D, Hariharan IK. Salvador promotes both cell cycle exit and apoptosis in Drosophila and is mutated in human cancer cell lines. Cell. 2002; 110: 467-478.

15. Seidel C, Schagdarsurengin U, Blumke K, Wurl P, Pfeifer GP, Hauptmann S, Taubert H, Dammann R. Frequent hypermethylation of MST1 and MST2 in soft tissue sarcoma. Mol Carcinog. 2007; 46: 865-871.

16. Zhao B, Li L, Wang L, Wang CY, Yu J, Guan KL. Cell detachment activates the Hippo pathway via cytoskeleton reorganization to induce anoikis. Genes Dev. 2012; 26: $54-68$.

17. Jimenez-Velasco A, Roman-Gomez J, Agirre X, Barrios M, Navarro G, Vazquez I, Prosper F, Torres A, Heiniger A. Downregulation of the large tumor suppressor 2 (LATS2/ KPM) gene is associated with poor prognosis in acute lymphoblastic leukemia. Leukemia. 2005; 19: 2347-2350.

18. Harvey KF, Zhang X, Thomas DM. The Hippo pathway and human cancer. Nat Rev Cancer. 2013; 13: 246-257.

19. Xie M, Zhang L, He CS, Hou JH, Lin SX, Hu ZH, Xu F, Zhao HY. Prognostic significance of TAZ expression in resected non-small cell lung cancer. J Thorac Oncol. 2012; 7:799-807.

20. Rashidian J, Le Scolan E, Ji X, Zhu Q, Mulvihill MM, Nomura D, Luo K. Ski regulates Hippo and TAZ signaling to suppress breast cancer progression. Sci Signal. 2015; 8:ra14.

21. Feil R, Fraga MF. Epigenetics and the environment: emerging patterns and implications. Nat Rev Genet. 2012; 13: 97-109.

22. Rodri'guez-Paredes M, Esteller M. Cancer epigenetics reaches mainstream oncology. Nat Med. 2011; 17: 330-339.

23. Mehta A, Dobersch S, Romero-Olmedo AJ, Barreto G. Epigenetics in lung cancer dignosis and therapy. Cancer Metastasis Rev. 2015; 34: 229-241.

24. Heller G, Altenberger C, Schmid B, Marhold M, Tomasich E, Ziegler B, Müllauer L, Minichsdorfer C, Lang G, End-Pfützenreuter A, Döme B, Arns BM, Fong KM, et al. DNA methylation transcriptionally regulates the putative tumor cell growth suppressor ZNF677 in non-small cell lung cancers. Oncotarget. 2015; 6: 394 408. doi:10.18632/oncotarget.2697.

25. Jia Y, Yang Y, Brock MV, Zhan Q, Herman JG, Guo M. Epigenetic regulation of DACT2, A key component of the Wnt signaling pathway in human lung cancer. J Pathol. 2013; 230: 194-204.

26. Han F, Liu W, Jiang X, Shi X, Yin L, Ao L, Cui Z, Li Y, Huang C, Cao J, Liu J. SOX30, a novel epigenetic silenced tumor suppressor, promotes tumor cell apoptosis by transcriptional activating p53 in lung cancer. Oncogene. 2015; 34: 4391-4402. 
27. W-b Liu, X Jiang, F Han, Y-h Li, H-q Chen, Y Liu, J Cao, J-y Liu. LHX6 acts as a novel potential tumour suppressor with epigenetic inactivation in lung cancer. Cell Death Dis. 2013; 4: e882.

28. Liu WB, Han F, Du XH, Jiang X, Li YH, Liu Y, Chen HQ, Ao L, Cui ZH, Cao J, Liu JY. Epigenetic silencing of Aristaless-like homeobox-4, a potential tumor suppressor gene associated with lung cancer. Int J Cancer. 2013; 134: 1311-1322.

29. Zhao B, Tumaneng K, Guan KL. The Hippo pathway in organ size control, tissue regeneration and stem cell selfrenewal. Nat Cell Biol. 2011; 13: 877-883.

30. Belinsky SA, Nikula KJ, Palmisano WA, Michels R, Saccomanno G, Gabrielson E, Baylin SB, Herman JG. Aberrant methylation of p16INK4a is an early event in lung cancer and a potential biomarker for early diagnosis. Proc Natl Acad Sci U S A. 1998; 95:11891-11896.

31. Takashi Sato, Eri Arai, Takashi Kohno, Koji Tsuta, Shun-ichi Watanabe, Kenzo Soejima, Tomoko Betsuyaku, Yae Kanai. DNA Methylation Profiles at Precancerous Stages Associated with Recurrence of Lung Adenocarcinoma PLoS One. 2013; 8: e59444.

32. Langevin SM, Kratzke RA, Kelsey KT. Epigenetics of lung cancer. Transl Res 2015; 165: 74-90.

33. Kokura K, Kaul SC, Wadhwa R, Nomura T, Khan MM, Shinagawa T, Yasukawa T, Colmenares C, Ishii S. The Ski protein family is required for MeCP2-mediated transcriptional repression. J Biol Chem. 2001; 276: 34115 34121.

34. Smedley D, Sidhar S, Birdsall S, Bennett D, Herlyn M, Cooper C, Shipley J. Characterization of chromosome 1 abnormalities in malignant melanomas. Genes Chromosomes Cancer. 2000; 28: 121-125.

35. Colmenares C, Heilstedt HA, Shaffer LG, Schwartz S, Berk M, Murray JC, Stavnezer E. Loss of the SKI protooncogene in individuals affected with 1p36 deletion syndrome is predicted by strain-dependent defects in Ski-/mice. Nat Genet. 2002; 30: 106-109.

36. Brodeur GM. Neuroblastoma: Biological insights into a clinical enigma. Nat Rev Cancer. 2003; 3: 203-216.

37. Le Scolan E, Zhu Q, Wang L, Bandyopadhyay A, Javelaud D, Mauviel A, Sun L, Luo K. Transforming growth factor- $\beta$ suppresses the ability of Ski to inhibit tumor metastasis by inducing its degradation. Cancer Res. 2008; 68: 3277-3285.
38. Wang P, Chen Z, Meng ZQ, Fan J, Luo JM, Liang W, Lin JH, Zhou ZH, Chen H, Wang K, Shen YH, Xu ZD, Liu LM. Dual role of Ski in pancreatic cancer cells: tumor-promoting versus metastasis-suppressive function. Carcinogenesis. 2009; 30: 1497-1506.

39. Dong J, Feldmann G, Huang J, Wu S, Zhang N, Comerford SA, Gayyed MF, Anders RA, Maitra A, Pan D. Elucidation of a Universal Size-Control Mechanism in Drosophila and Mammals. Cell. 2007; 130: 1120-1133.

40. Yu FX, Guan KL. The Hippo pathway: Regulators and regulations. Genes Dev. 2013; 27: 355-371.

41. Cordenonsi M, Zanconato F, Azzolin L, Forcato M, Rosato A, Frasson C, Inui M, Montagner M, Parenti AR, Poletti A, Daidone MG, Dupont S, Basso G, et al. The Hippo transducer TAZ confers cancer stem cell-related traits on breast cancer cells. Cell. 2011; 147: 759-772.

42. Xie M, He CS, Wei SH, Zhang L. Notch-1 contributes to epidermal growth factor receptor tyrosine kinase inhibitor acquired resistance in non-small cell lung cancer in vitro and in vivo. Eur J Cancer. 2013; 49: 3559-3572.

43. Travis WD, Brambilla E, Noguchi M, Nicholson AG, Geisinger KR, Yatabe Y, Beer DG, Powell CA, Riely GJ, Van Schil PE, Garg K, Austin JH, Asamura H, et al. International association for the study of lung cancer/ american thoracicsociety/european respiratory society international multidisciplinary classification of lung adenocarcinoma. J Thorac Oncol. 2011; 6: 244-285.

44. Vallières E, ShepherdFA, Crowley J, Van Houtte P, Postmus PE, Carney D, Chansky K, Shaikh Z, Goldstraw P. The IASLC Lung Cancer Staging Project: proposals regarding the relevance of TNM in the pathologic staging of small cell lung cancer in the forthcoming (seventh) edition of the TNM classification for lung cancer. J Thorac Oncol. 2009; 4: 1049-1059.

45. Fukuchi M, Nakajima M, Fukai Y, Miyazaki T, Masuda N, Sohda M, Manda R, Tsukada K, Kato H, Kuwano H. Increased expression of c-Ski as a co-repressor in transforming growth factor- $\beta$ signaling correlates with progression of esophageal squamous cell carcinoma. Int $\mathbf{J}$ Cancer. 2004; 108: 818-824.

46. Livasy CA, Moore D, Cance WG, Lininger RA. Focal adhesion kinase overexpression in endometrial neoplasia. Appl Immunohistochem Mol Morphol. 2004; 12: 342-345. 